Sains Malaysiana 48(10)(2019): 2151-2159

http://dx.doi.org/10.17576/jsm-2019-4810-10

\title{
Benchmarking in silico Tools for the Functional Assessment of DNA Variants using a Set of Strictly Pharmacogenetic Variants
}

(Ujian Tanda Aras Alat in silico untuk Penilaian Kesan Fungsian Varian DNA menggunakan Varian Farmakogenetik Terpilih)

\author{
ENG WeE CHUA* \& CHIAN SIANG GOH
}

\begin{abstract}
Predictive algorithms are important tools for translating genomic data into meaningful functional annotations. In this work, we benchmarked the performance of eight prediction methods using a set of strictly pharmacogenetic variants. We first compiled a set of damaging or neutral variants that affected pharmacogenes from two online databases. We then cross-checked their functional impacts against the predictions given by the chosen tools. Of the eight methods, SIFT

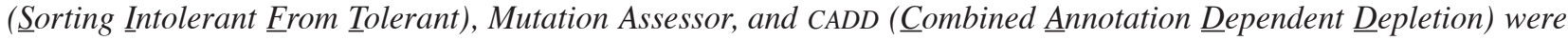
the top performers in predicting the functional relevance of a variant. The performance of SIFT surpassed that of CADD despite its much simpler algorithm, correctly identifying $66.91 \%$ of the damaging variants and $84.38 \%$ of the neutral variants. SIFT assumes that important DNA bases within a gene are conserved and not amenable to substitution. Overall, none of the prediction methods struck a balance between sensitivity and specificity. For instance, we noted that CADD was very sensitive in detecting the damaging variants (89.21\%); however, it also mispredicted a large fraction of the neutral variants $(43.75 \%)$. We then trialled a consensus approach whereby the functional significance of a variant is defined by agreement between at least three prediction methods. The approach performed better than all the tools deployed alone, detecting $84.17 \%$ of the deleterious variants and $70.97 \%$ of the neutral variants. A prediction method that integrates an assortment of algorithms, each assigned an empirically optimised weighting, may be established in the future for the functional assessment of pharmacogenetic variants.
\end{abstract}

Keywords: Deleteriousness; functional impact; pharmacogenetic variant; predictive algorithm; receiver operating characteristic analysis

\section{ABSTRAK}

Algoritma ramalan merupakan alat yang penting dalam menterjemahkan data genom kepada anotasi fungsian yang lebih bermakna. Dalam kajian ini, kami menilai prestasi lapan kaedah ramalan dalam mengenal pasti kesan fungsian varian farmakogenetik. Kami mengumpulkan varian farmakogenetik yang neutral atau merosakkan fungsi protein daripada dua pangkalan data atas talian. Kemudian, kami membandingkan kesan fungsian setiap varian tersebut dengan ramalan

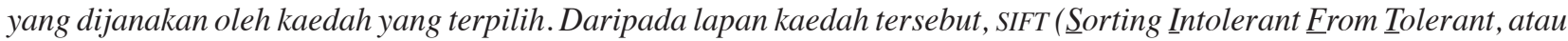

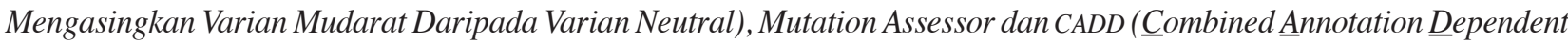
Depletion, atau Kesusutan Bersandarkan Anotasi Gabungan) adalah terbaik dalam menentukan kesan fungsian sesuatu varian farmakogenetik. SIFT mencapai prestasi yang lebih baik daripada CADD walaupun algoritmanya lebih ringkas. Kaedah tersebut dapat mengenal pasti $66.91 \%$ varian yang mencacatkan fungsi protein dan $84.38 \%$ varian neutral. Ramalan SIFT adalah berasaskan anggapan bahawa bes DNA yang penting dalam sesuatu gen adalah terabadi dan tidak boleh ditukar ganti. Secara keseluruhan, tiada kaedah ramalan mencapai keseimbangan antara kepekaan dan kekhususan diagnostik. Contohnya, kami mendapati bahawa CADD sangat sensitif dalam mengesankan varian mudarat (89.21\%); tetapi, CADD juga membuat ramalan yang salah terhadap kesan fungsian sekelompok besar varian neutral (43.75\%). Seterusnya, kami menaksirkan kesan fungsian varian dengan berdasarkan persetujuan antara sekurang-kurangnya tiga kaedah ramalan. Pendekatan konsensus ini didapati lebih baik daripada menggunakan mana-mana kaedah secara berasingan. Pendekatan tersebut mampu mengesankan $84.17 \%$ varian mudarat dan $70.97 \%$ varian neutral. Kaedah ramalan yang menggabungkan pelbagai algoritma, dengan setiap satunya diberi pemberatan yang ditentukan secara empirik, mungkin dibangunkan pada masa hadapan bagi menilai impak fungsian varian farmakogenetik dengan lebih berkesan.

Kata kunci: Algoritma ramalan; analisis penerimaan pengoperasian lengkung; impak fungsian; mudarat; varian farmakogenetik 


\section{INTRODUCTION}

In silico algorithms for estimating the functional effects of DNA variants render genomic data meaningful. The basis for pinpointing a functionally significant variant is fairly intuitive: Gene regions encoding key biological functions are conserved and variation in these segments is nonpermissible and therefore detrimental. This constitutes a chief assumption at the core of many predictive algorithms (Adzhubei et al. 2010; Kircher et al. 2014; Ng \& Henikoff 2003; Reva et al. 2011; Tang \& Thomas 2016). However, the assumption may fall short of capturing variants that impair less crucial processes such as drug disposition. For instance, individuals deficient in CYPs (cytochromes P450) lead entirely normal lives apart from the occasional distress when they are given medications dependent on the enzymes for elimination. This has allowed an assemblage of quiescent $C Y P$ variants to persist in the general population at relatively high frequencies, in contrast to their more penetrant, disease-causing counterparts (Gardiner \& Begg 2006).

Hence, we speculated that in silico algorithms tailored for the assessment of pathogenicity might be unsuitable for pharmacogenetics variants. For instance, in our preliminary analysis of a well-known prediction tool, Combined Annotation Dependent Depletion or CADD, we noted that the tool gave an unacceptably large number of false-positives. CADD is a relatively novel member of the growing family of predictive algorithms. Owing to its purported versatility, being effective against both coding and non-coding DNA variants, CADD is steadily gaining popularity in pharmacogenetic research (Bush et al. 2016). However, one notable caveat of CADD is that it gives much weight to the influence of purifying selection when assessing the functional relevance of a DNA variant, which may be weak against pharmacogenetic variants and thus somewhat irrelevant (Li et al. 2014).

Further, pharmacogenetic variants have been shown to induce various molecular changes that could be hard to detect; in some instances, they alter enzyme activity in a substrate-specific manner (Sakuyama et al. 2008; Yu et al. 2002). In this work, we evaluated the performance of eight prediction methods with distinct mechanisms of gauging the functional relevance of a DNA variant. We theorised that a combination of several methods would outperform individual algorithms used alone in predicting the functional effects of pharmacogenetic variants.

\section{MATERIALS AND METHODS}

\section{A BENCHMARKING SET OF MISSENSE VARIANTS}

We collated a selective set of 170 missense variants from two online databases (Table 1), Human Cytochrome P450 (CYP) Allele Nomenclature Database (http://www. cypalleles.ki.se/) and TPMT Alleles (https://www.imh.liu. se/tpmtalleles?l=en), and cross-checked their functional effects against the predictions given by chosen algorithms.
These variants are strictly pharmacogenetic in that they have been shown to induce varied extents of changes in drug metabolism, but not manifest disease phenotypes (Apweiler et al. 2004). CYP enzymes serving a key physiological function, such as those that metabolise endogenous hormones, were excluded from our analysis. This was a criterion not included in previous work. For instance, Hao et al. (2010), in their analysis of phase II metabolising enzymes, did not exclude genes that had been implicated in the pathogenesis of a disease, such as UGTIA1. The gene encodes a protein that conjugates extraneous compounds and facilitates their removal; damaging UGTIAl mutations are known to cause Gilbert Syndrome and familial neonatal hyperbilirubinaemia. Inclusion of pharmacogenetic variants with ambiguous properties could have affected the conclusions that they drew from their findings.

TABLE 1. Pharmacogenetic variants with known functional effects. These variants were compiled from two online databases, Human CYP Allele Nomenclature and TPMT Alleles

\begin{tabular}{lcc}
\hline Gene & Decreased- or null-function & Normal \\
\hline CYP1A1 & 7 & 1 \\
CYP1A2 & 15 & 1 \\
CYP2A6 & 12 & 1 \\
CYP2B6 & 5 & 5 \\
CYP2C8 & 30 & 6 \\
CYP2C9 & 5 & \\
CYP2C19 & 13 & 6 \\
CYP2D6 & 1 & 2 \\
CYP2E1 & 4 & 1 \\
CYP2J2 & 8 & 6 \\
CYP3A4 & 2 & \\
CYP3A5 & 1 & \\
CYP4A11 & 1 & \\
CYP4F2 & 2 & 31 \\
CYP26A1 & 33 & \\
TPMT & 139 & \\
\hline Total & & \\
\hline
\end{tabular}

\section{PREDICTION OF FUNCTIONAL CONSEQUENCES}

Eight prediction tools were tested (Table 2). They were selected based on their previously reported performance and distinct mechanisms that ranged from straightforward estimation of the evolutionary pressure imposed on a protein to merging various conservation and functional metrics into one prediction (Gray et al. 2012; IngelmanSundberg et al.2018). Besides evaluating the performance of individual prediction tools, we also tested a consensus strategy whereby agreement between at least three tools was used as the basis for qualifying a DNA variant as 


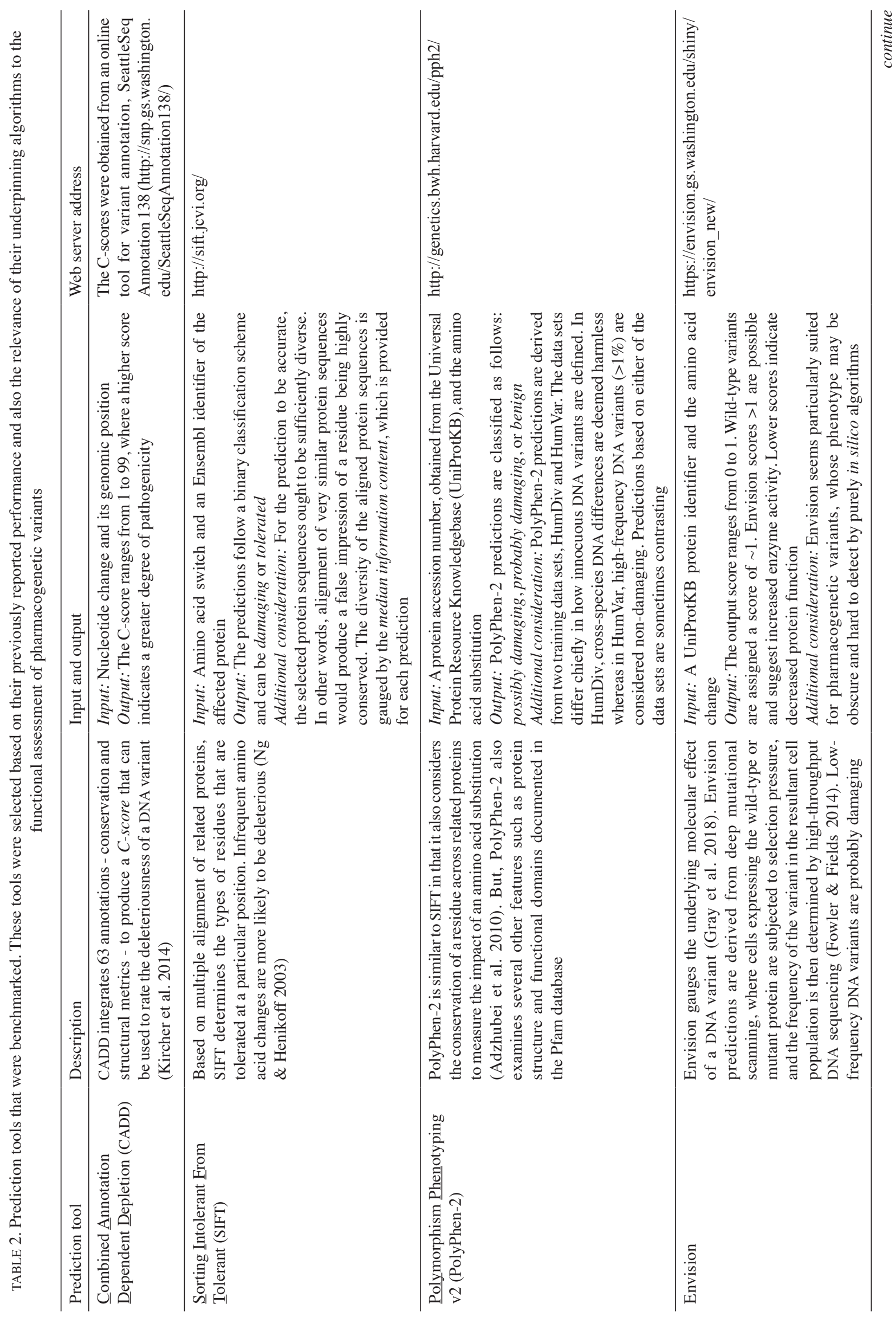




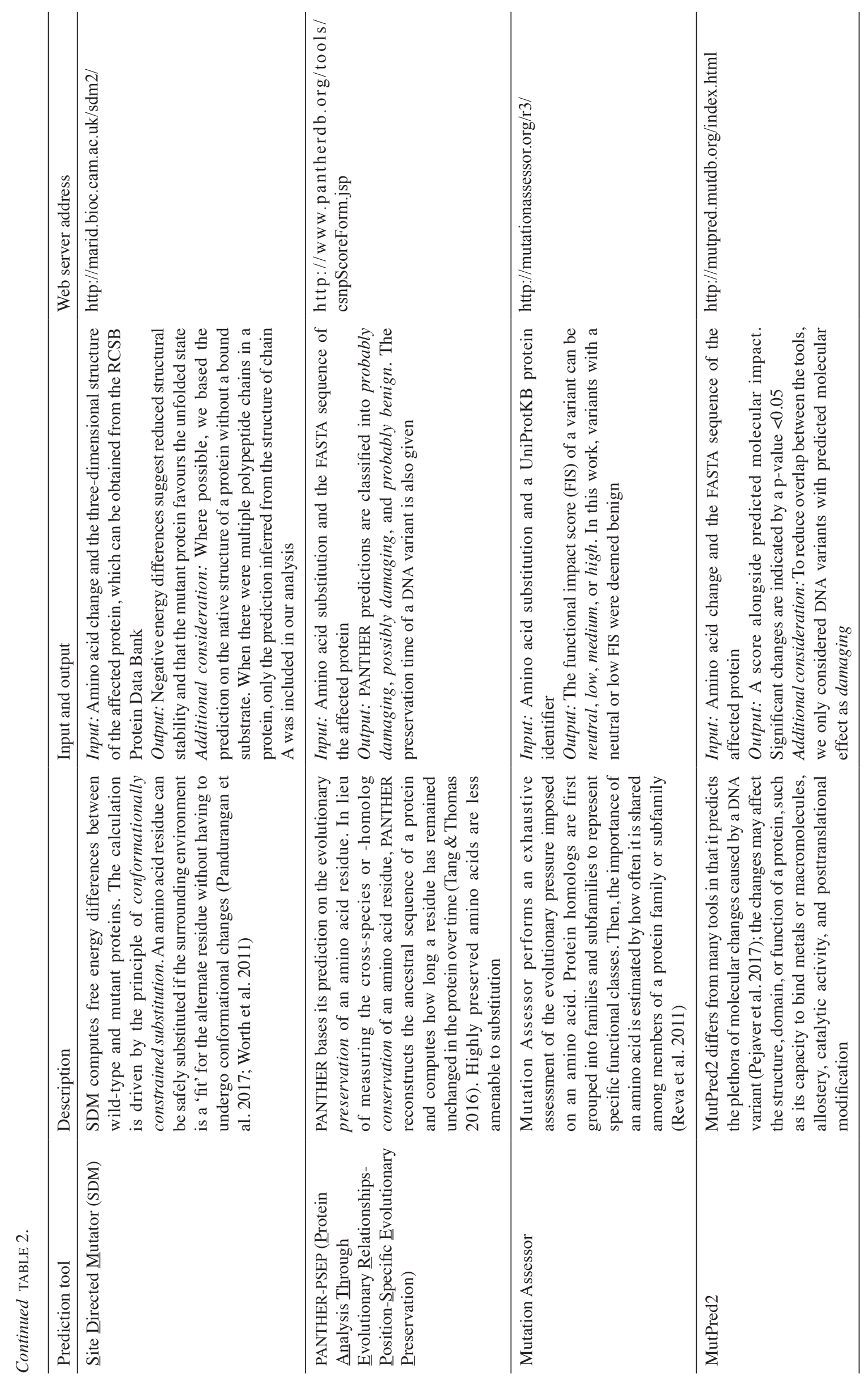


damaging (Frousios et al. 2013). The accuracy of a prediction tool was defined by the following formula:

$$
\frac{a+b}{2}
$$

where $a$ and $b$ were the fractions of the correctly identified damaging and neutral variants, respectively.

\section{STATISTICAL ANALYSIS}

Receiver operating characteristic (ROC) analysis was performed using easyROC (Goksuluk et al. 2016). Youden Index was chosen as the method for estimating optimal cut points.

\section{RESULTS AND DISCUSSION}

We first evaluated the diagnostic performance of CADD, Envision, and SDM, as the tools had not been tested on pharmacogenetic variants. ROC analysis showed that CADD and Envision, but not SDM, were reasonably accurate in detecting variants that affected pharmacogenes, yielding areas under the curve of 0.73 and 0.75 , respectively (Figure 1 \& Table 2). The optimal discriminating $\mathrm{C}$-score was 8.34, appreciably lower than that recommended for diseasecausing variants (Kircher et al. 2014). A large fraction of the damaging variants $(89.21 \%)$ received a C-score $>8.34$ and were therefore correctly identified; however, many neutral variants were also misclassified (43.75\%). Envision was much less sensitive than CADD, and a subthreshold score $<0.86$ pinpointed only $54.68 \%$ of the damaging variants. The drawback was offset by a relatively low rate of false positives (12.5\%). Of the three methods, SDM was the worst-performing. It was unable to distinguish variants with differing functional impact (Table 2), suggesting that diminished stability was not a major attribute of mutant drug-metabolising proteins.

We then compared the performance of CADD, Envision, and SDM with other predictive algorithms, which are established tools in the functional assessment of diverse types of DNA variants (Chan 2013; Flanagan et al. 2010; Hao et al. 2011, 2010; Valdmanis et al. 2009; Zou et al. 2011). What set our work apart from previous analyses was that we used a narrow definition of pharmacogenetic variants and excluded those that affected CYP-mediated metabolism of crucial endogenous substrates. For instance, CYP21A2 encodes an enzyme involved in the production of adrenal hormones. Inactivating $C Y P 21 A 2$ variants cause congenital adrenal hyperplasia (Yu et al. 2011). Also, many non-CYP pharmacogenes have been implicated in the development of human diseases (Gottesman \& Ambudkar 2001).
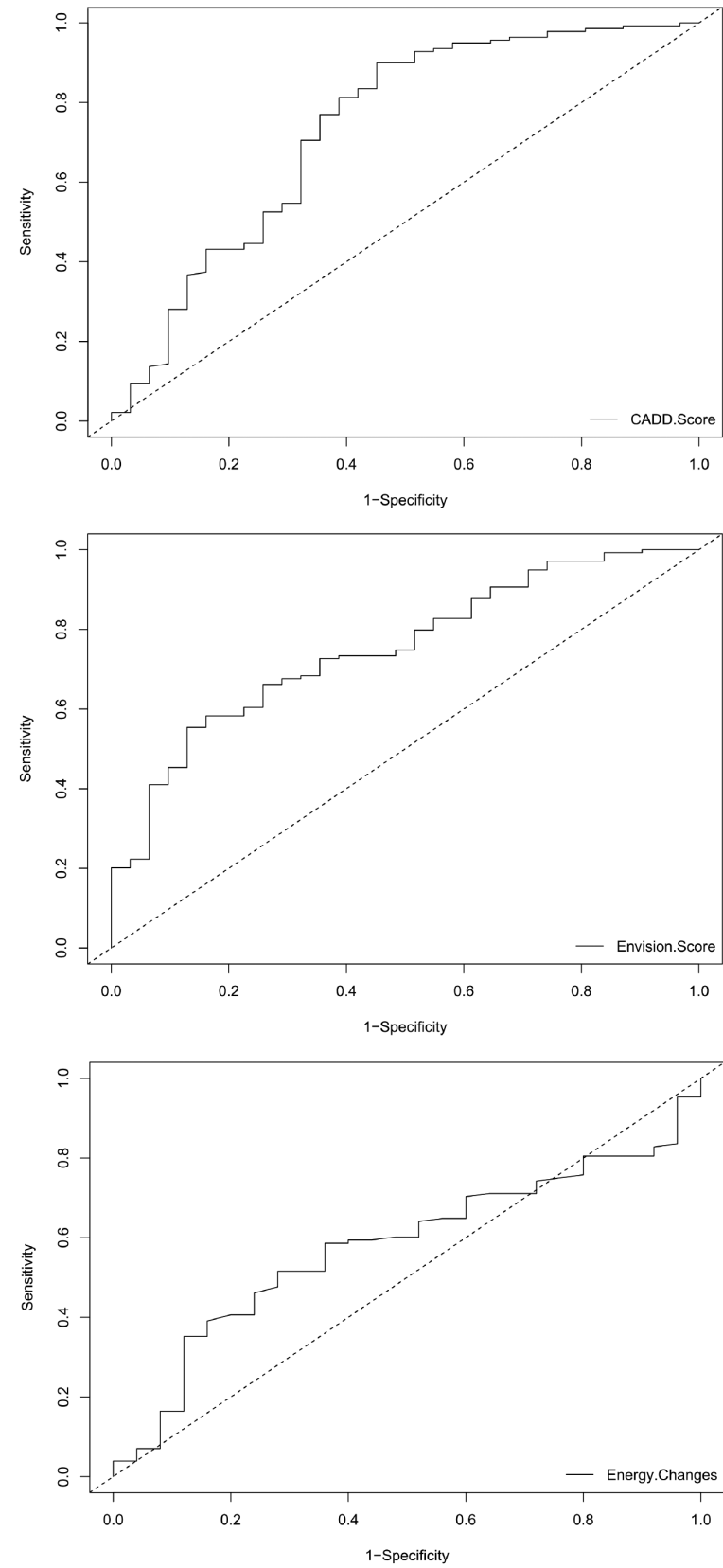

FIGURE 1. Receiver operating characteristic analysis of CADD, Envision, and SDM scores for defining functionally relevant pharmacogenetic variants

TABLE 3. Receiving operating characteristic analysis

\begin{tabular}{ccccc}
\hline Method & Area under the curve $\left( \pm \mathrm{SE}^{*}\right)$ & $\mathrm{p}$ value & Optimal cut-off & Youden's optimal criterion \\
\hline CADD & $0.73 \pm 0.06$ & $5 \times 10^{-5}$ & 8.34 & 0.45 \\
Envision & $0.75 \pm 0.05$ & 0 & 0.86 & 0.42 \\
SDM & $0.58 \pm 0.06$ & 0.17 & -0.58 & 0.24
\end{tabular}

*Standard error 


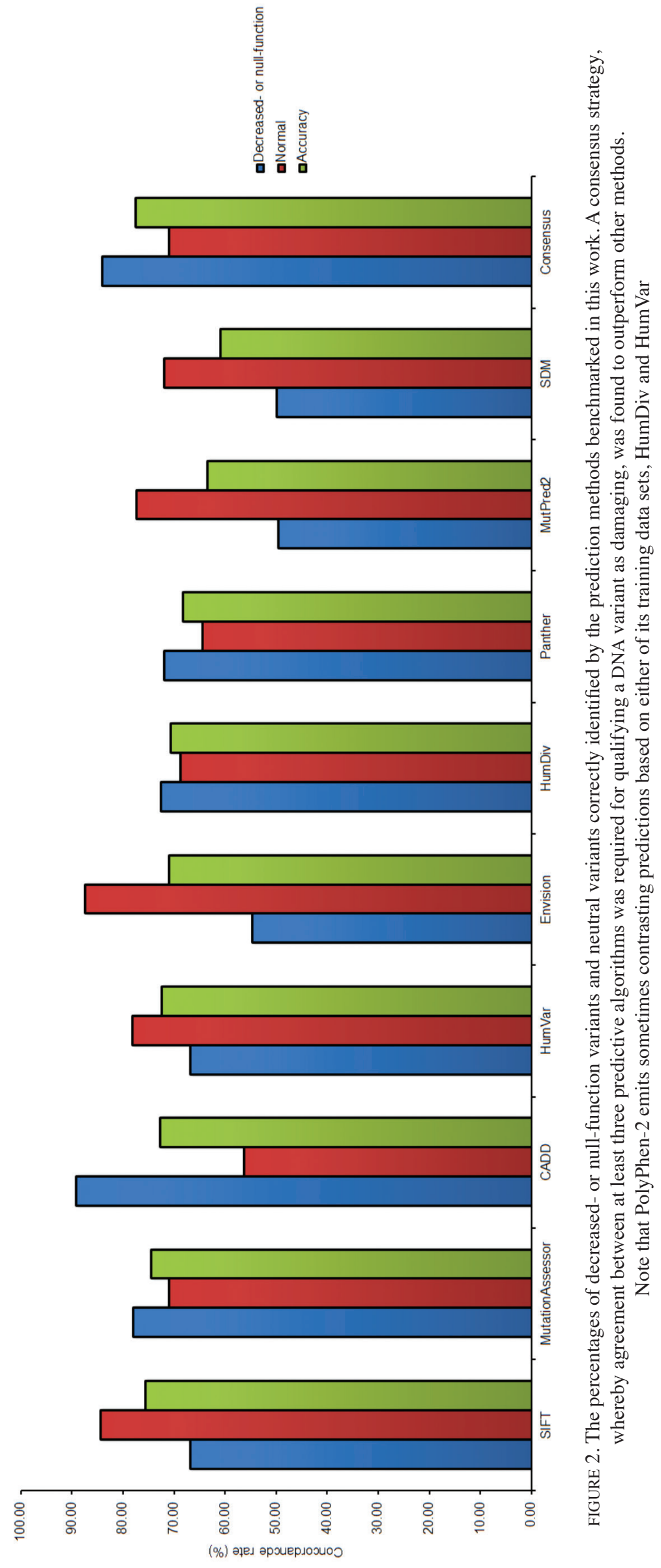


Although CADD and Envision are touted as having a thorough prediction scheme, they have not outperformed SIFT, Mutation Assessor, or PolyPhen-2 in our analysis (Figure 2). Of the eight tested tools, SIFT gave the best performance despite its simple algorithm; its accuracy reached $75.65 \%$. Mutation Assessor followed SIFT closely with an accuracy rate of $74.53 \%$. It is worth noting that SIFT and Mutation Assessor have very similar algorithms (Table 2). Both methods derive their predictions from gauging the persistence of important amino acids throughout evolution; therefore, they may tend to underestimate the functional impact of pharmacogenetic variants. Indeed, we found that SIFT was better at predicting the neutrality of pharmacogenetic variants than their deleteriousness (Figure 2). Our result concurs with that of a previous study showing that pharmacogenetic variants were almost indistinguishable from harmless DNA changes that occurred throughout the human genome (Li et al. 2014).

In previous analyses, PolyPhen-2, or its older version, was often noted to surpass SIFT in detecting damaging DNA variants (Chan 2013; Flanagan et al. 2010; Gray et al. 2012). However, we found that PolyPhen-2 performed less well than expected. PolyPhen-HumVar correctly identified $66.91 \%$ of the decreased- or null-function variants and $78.13 \%$ of the innocuous variants. PolyPhen-HumDiv was better at predicting damaging variants but fared worse against neutral variants (72.66\% vs.68.75\%). Both models detected fewer neutral variants than did SIFT, lowering their overall accuracy. The discrepancy between our result and those of previous work could be ascribed to the different variant sets that were used to benchmark the tools.

Overall, none of the tested tools struck a balance between the rates of true positives and false positives (Figure 2). Therefore, we trialled a consensus approach whereby the prediction of functional relevance was based on agreement between at least three methods. This approach attained a high degree of sensitivity $(84.17 \%)$ without yielding an unacceptable rate of false positives (29.03\%). The impact of DNA variants could arise from disparate mechanisms, the assessment of which requires a multipronged approach. The complex effect of DNA variants may explain why the consensus strategy performed better than other methods used alone. A deleterious variant might evade detection by some tools but not others. Future work may benefit from a detailed analysis of pharmacogenetic variants to pinpoint the features that contribute most substantially to their damaging consequences. For consensus prediction, the included tools may be carefully chosen to optimise its accuracy. Moreover, each tool may be assigned a weighting according to its mechanism of prediction. For instance, the superior performance of SIFT and Mutation Assessor suggests that pharmacogenetic variants may experience weak yet significant evolutionary pressure; hence, these methods can be given greater importance when combined with others to predict the functional effect of a pharmacogenetic variant (IngelmanSundberg et al. 2018).

\section{STUDY LIMITATIONS}

Our study has several limitations that should be considered. First, in our benchmarking set of variants, the damaging variants far outnumbered the neutral variants. A slight change in the number of correctly predicted neutral variants would alter the rate of true negatives appreciably. Second, we assumed that the influence of a DNA variant on enzyme function is consistent across different substrates. This contradicts prior observations that some pharmacogenetic variants enhanced the action of an enzyme on some of its substrates while decreasing its activity towards other substrates (Sakuyama et al. 2008; Yu et al. 2002). Third, we did not iteratively test the effect of an amino acid substitution in each polypeptide that comprises a protein. Instead, we assumed that the amino acid change in any of the polypeptides should produce a similar effect on the structural stability of the protein.

\section{CONCLUSION}

Accurately predicting the functional impact of a DNA variant is a long-standing conundrum in genomics research. Disagreement between algorithms is not uncommon, and the performance of a tool is known to vary across variant types (Flanagan et al. 2010; Mather et al. 2016). These problems could be more severe in the analysis of pharmacogenetic variants, as the current predictive algorithms are not trained for gauging nonpathogenic deleteriousness. Thus, assessing the efficacy of different algorithms in deciphering the functional impact of pharmacogenetic variants formed the basis of our work.

We have determined that the top-performing prediction tools, when benchmarked against a set of strictly defined pharmacogenetic variants, were SIFT, Mutation Assessor, and CADD. However, none of them struck an optimal balance between sensitivity and specificity. The accuracy of prediction was highest (77.57\%) when we adopted a consensus strategy whereby the deleteriousness of a variant was defined by agreement between at least three methods. Therefore, future investigations may focus on designing a comprehensive method for assessing the functional relevance of pharmacogenetic variants, by combining a variety of carefully chosen tools and assigning each of them a weighting based on their mechanism of prediction. The development of the method should be facilitated by the expanding data sets of well-annotated pharmacogenetic variants.

\section{ACKNOWLEDGEMENTS}

This work was supported by a university grant, Geran Galakan Penyelidik Muda (GGPM-2016-055). C.S.G. carried out much of the in silico analysis. E.W.C. designed the study, performed additional analysis, and wrote the manuscript. 


\section{REFERENCES}

Adzhubei, I.A., Schmidt, S., Peshkin, L., Ramensky, V.E., Gerasimova, A., Bork, P., Kondrashov, A.S. \& Sunyaev, S.R. 2010. A method and server for predicting damaging missense mutations. Nature Methods 7(4): 248-249.

Apweiler, R., Bairoch, A., Wu, C.H., Barker, W.C., Boeckmann, B., Ferro, S., Gasteiger, E., Huang, H., Lopez, R., Magrane, M., Martin, M.J., Natale, D.A., O’Donovan, C., Redaschi, N. \& Yeh, L.S. 2004. UniProt: The universal protein knowledgebase. Nucleic Acids Research 32(Database issue): D115-D119.

Bush, W.S., Crosslin, D.R., Owusu-Obeng, A., Wallace, J., Almoguera, B., Basford, M.A., Bielinski, S.J., Carrell, D.S., Connolly, J.J., Crawford, D., Doheny, K.F., Gallego, C.J., Gordon, A.S., Keating, B., Kirby, J., Kitchner, T., Manzi, S., Mejia, A.R., Pan, V., Perry, C.L., Peterson, J.F., Prows, C.A., Ralston, J., Scott, S.A., Scrol, A., Smith, M., Stallings, S.C., Veldhuizen, T., Wolf, W., Volpi, S., Wiley, K., Li, R., Manolio, T., Bottinger, E., Brilliant, M.H., Carey, D., Chisholm, R.L., Chute, C.G., Haines, J.L., Hakonarson, H., Harley, J.B., Holm, I.A., Kullo, I.J., Jarvik, G.P., Larson, E.B., McCarty, C.A., Williams, M.S., Denny, J.C., Rasmussen-Torvik, L.J., Roden, D.M. \& Ritchie, M.D. 2016. Genetic variation among 82 pharmacogenes: The PGRNseq data from the eMERGE network. Clinical Pharmacology \& Therapeutics 100(2): 160-169.

Chan, A.O. 2013. Performance of in silico analysis in predicting the effect of non-synonymous variants in inherited steroid metabolic diseases. Steroids 78(7): 726-730.

Flanagan, S.E., Patch, A.M. \& Ellard, S. 2010. Using SIFT and PolyPhen to predict loss-of-function and gain-of-function mutations. Genetic Testing \& Molecular Biomarkers 14(4): 533-537.

Fowler, D.M. \& Fields, S. 2014. Deep mutational scanning: a new style of protein science. Nature Methods 11(8): 801-807.

Frousios, K., Iliopoulos, C.S., Schlitt, T. \& Simpson, M.A. 2013. Predicting the functional consequences of non-synonymous DNA sequence variants-evaluation of bioinformatics tools and development of a consensus strategy. Genomics 102(4): 223-228.

Gardiner, S.J. \& Begg, E.J. 2006. Pharmacogenetics, drugmetabolizing enzymes, and clinical practice. Pharmacological Reviews 58(3): 521-590.

Goksuluk, D., Korkmaz, S., Zararsiz, G. \& Karaağaoğlu, A.E. 2016. easyROC: An interactive web-tool for ROC curve analysis using $\mathrm{R}$ language environment. The R Journal 8(2): 213-230.

Gottesman, M.M. \& Ambudkar, S.V. 2011. Overview: ABC transporters and human disease. Journal of Bioenergetics and Biomembranes 33(6): 453-458.

Gray, V.E., Hause, R.J., Luebeck, J., Shendure, J. \& Fowler, D.M. 2018. Quantitative missense variant effect prediction using large-scale mutagenesis data. Cell Systems 6(1): 116-124.

Gray, V.E., Kukurba, K.R. \& Kumar, S. 2012. Performance of computational tools in evaluating the functional impact of laboratory-induced amino acid mutations. Bioinformatics 28(16): 2093-2096.

Hao, D., Feng, Y., Xiao, R. \& Xiao, P.G. 2011. Non-neutral nonsynonymous single nucleotide polymorphisms in human $\mathrm{ABC}$ transporters: The first comparison of six prediction methods. Pharmacological Reports 63(4): 924-934.

Hao, D., Xiao, P. \& Chen, S. 2010. Phenotype prediction of nonsynonymous single nucleotide polymorphisms in human phase II drug/xenobiotic metabolizing enzymes: Perspectives on molecular evolution. Science China Life Sciences 53(10): 1252-1262.

Ingelman-Sundberg, M.,Mkrtchian, S.,Zhou, Y.\& Lauschke, V.M. 2018. Integrating rare genetic variants into pharmacogenetic drug response predictions. Human Genomics 12(1): 26.

Kircher, M., Witten, D.M., Jain, P., O'roak, B.J., Cooper, G.M. \& Shendure, J. 2014. A general framework for estimating the relative pathogenicity of human genetic variants. Nature Genetics 46(3): 310-315.

Li, B., Seligman, C., Thusberg, J., Miller, J.L., Auer, J., WhirlCarrillo, M., Capriotti, E., Klein, T.E. \& Mooney, S.D. 2014. In silico comparative characterization of pharmacogenomic missense variants. BMC Genomics 15(Suppl 4): S4.

Mather, C.A., Mooney, S.D., Salipante, S.J., Scroggins, S., Wu, D., Pritchard, C.C. \& Shirts, B.H. 2016. CADD score has limited clinical validity for the identification of pathogenic variants in noncoding regions in a hereditary cancer panel. Genetic Medicine 18(12): 1269-1275.

Ng, P.C. \& Henikoff, S. 2003. SIFT: predicting amino acid changes that affect protein function. Nucleic Acids Research 31(13): 3812-3814.

Pandurangan, A.P., Ochoa-Montaño, B., Ascher, D.B. \& Blundell, T.L. 2017. SDM: A server for predicting effects of mutations on protein stability. Nucleic Acids Research 45(W1): W229-W235.

Pejaver, V., Urresti, J., Lugo-Martinez, J., Pagel, K.A.,Lin, G.N., Nam, H., Mort, M., Cooper, D.N., Sebat, J., Iakoucheva, L.M., Mooney, S.D. \& Radivojac, P. 2017. MutPred2: Inferring the molecular and phenotypic impact of amino acid variants. bioRxiv doi: https://doi.org/10.1101/134981.

Reva, B.,Antipin, Y. \& Sander, C. 2011. Predicting the functional impact of protein mutations: Application to cancer genomics. Nucleic Acids Research 39(17): e118.

Sakuyama, K., Sasaki, T., Ujiie, S., Obata, K., Mizugaki, M., Ishikawa, M. \& Hiratsuka, M. 2008. Functional characterization of 17 CYP2D6 allelic variants (CYP2D6.2, 10, 14A-B, 18, 27, 36, 39, 47-51, 53-55, and 57). Drug Metabolism and Disposition 36(12): 2460-2467.

Tang, H. \& Thomas, P.D. 2016. PANTHER-PSEP: Predicting disease-causing genetic variants using position-specific evolutionary preservation. Bioinformatics 32(14): 2230-2232.

Valdmanis, P.N., Verlaan, D.J. \& Rouleau, G.A. 2009. The proportion of mutations predicted to have a deleterious effect differs between gain and loss of function genes in neurodegenerative disease. Human Mutation 30(3): E481-E489.

Worth, C.L., Preissner, R. \& Blundell, T.L. 2011. SDM-A server for predicting effects of mutations on protein stability and malfunction. Nucleic Acids Research 39(Web Server issue): W215-W222.

Yu, A., Kneller, B.M., Rettie, A.E. \& Haining, R.L. 2002. Expression, purification, biochemical characterization, and comparative function of human cytochrome P450 2D6.1, 2D6.2, 2D6.10, and 2D6.17 allelic isoforms. Journal of Pharmacology and Experimental Therapeutics 303(3): 1291-1300.

Yu, Y., Wang, J., Huang, X., Wang, Y., Yang, P., Li, J., Tsuei, S.H., Shen, Y. \& Fu, Q. 2011. Molecular characterization of 25 Chinese pedigrees with 21-hydroxylase deficiency. Genetic Testing and Molecular Biomarkers 15(3): 137-142.

Zou, M., Baitei, E.Y., Alzahrani, A.S., Parhar, R.S., Al-Mohanna, F.A., Meyer, B.F. \& Shi, Y. 2011. Mutation prediction by 
PolyPhen or functional assay, a detailed comparison of CYP27B1 missense mutations. Endocrine 40(1): 14-20.

Faculty of Pharmacy

Universiti Kebangsaan Malaysia

Jalan Raja Muda Abdul Aziz

50300 Kuala Lumpur, Federal Territory

Malaysia
*Corresponding author; email: cew85911@ukm.edu.my

Received: 19 August 2018

Accepted: 9 September 2019 